\title{
Characteristics of Organic Matter Pores and the Relationship with Current Pressure System of Lower Silurian Longmaxi Shales in Dingshan Field, Southern Sichuan, China
}

\author{
Qian Cao $\mathbb{D}^{1,2,3}$ Ke Jiang $\mathbb{D}^{1},{ }^{4}$ Zhentao Wen, ${ }^{5}$ Xingzhi Wang, ${ }^{1}$ Minghui Qi, ${ }^{2,3}$ \\ and Zhongshan Yin ${ }^{2,3}$ \\ ${ }^{1}$ School of Earth Science and Technology, Southwest Petroleum University, Chengdu 610500, China \\ ${ }^{2}$ Shale Gas Evaluation and Exploitation Key Laboratory of Sichuan Province, Chengdu 610091, China \\ ${ }^{3}$ Sichuan Keyuan Testing Center of Engineering Technology, Chengdu 610091, China \\ ${ }^{4}$ State Key Laboratory of Oil and Gas Reservoir Geology and Exploitation, Chengdu University of Technology, \\ Chengdu 610059, China \\ ${ }^{5}$ Exploration and Development Research Institute of Southwest Oil and Gas Company, SINOPEC, Chengdu, Sichuan 610041, China
}

Correspondence should be addressed to Qian Cao; 421664225@qq.com and Ke Jiang; jklxyh1994@163.com

Received 24 March 2021; Revised 31 July 2021; Accepted 8 September 2021; Published 8 October 2021

Academic Editor: Andrea Brogi

Copyright (c) 2021 Qian Cao et al. This is an open access article distributed under the Creative Commons Attribution License, which permits unrestricted use, distribution, and reproduction in any medium, provided the original work is properly cited.

\begin{abstract}
Organic matter pores (OMP) provide significant storage space for hydrocarbons in lower Silurian Longmaxi shales in the Dingshan field of southern Sichuan, China. The distributions of organic matter and the different OMP structure parameters were characterized through Ar-ion polishing, scanning electron microscopy (SEM), and image analysis software for shale samples of different wells. The research results indicated that organic matter has been divided into two categories based on its occurrence, location, and its relationship with authigenic minerals: organic matter in situ and migrated organic matter. OMP for organic matter in situ are mainly micropores mostly arranged isolatedly, while in migrated organic matter pores show larger sizes and higher roundness. The development of OMP in samples is predominantly controlled by the formation pressure. The existence of overpressure alleviated the stress on the rock skeleton, causing the compaction of some migrated organic matters to lag or decrease. This played a positive role in protecting the development of pores in the interior and edge of the rock skeleton, and it can also induce the development of microfractures in shale. The protective effect of formation pressure on organic pores was provided for understanding the exploration and exploitation of Longmaxi shales in the study area.
\end{abstract}

\section{Introduction}

In recent years, investigations on the pore type, pore size, and pore structure characteristic parameters of mud shale have been conducted providing significant achievements under an increasing interest in unconventional hydrocarbons [1-3]. Previous studies on organic-rich shales, such as Barnett, Woodford, Marcellus, and Wufeng-Longmaxi shales, have found that porosity in organic matter represents a significant fraction of the reservoir space [4-6]. The formation and evolution of organic matter pores play an important role in the storage and migration of oil and gas in shale reservoirs, increasing the specific surface area and pore volume of shale providing storage space for shale gas [6-8].

As reported in literature, the in situ organic matter represents the original organic matter and its alteration products. The occurrence of solid bitumen is generally regarded as the secondary product from oil-prone kerogen by thermal degradation and hydrocarbon generation, that is, bitumen and hydrocarbon can be generated in a source rock and then migrated to another [9]. During the process of thermal maturation, kerogen is broken down to bitumen [4, 10-13]. Jacob [14] proposed the concept of "migrabitumen" for the first time. He claimed that migrabitumen ("solid petroleum bitumen"), as a high viscosity fluid, is often distributed in 

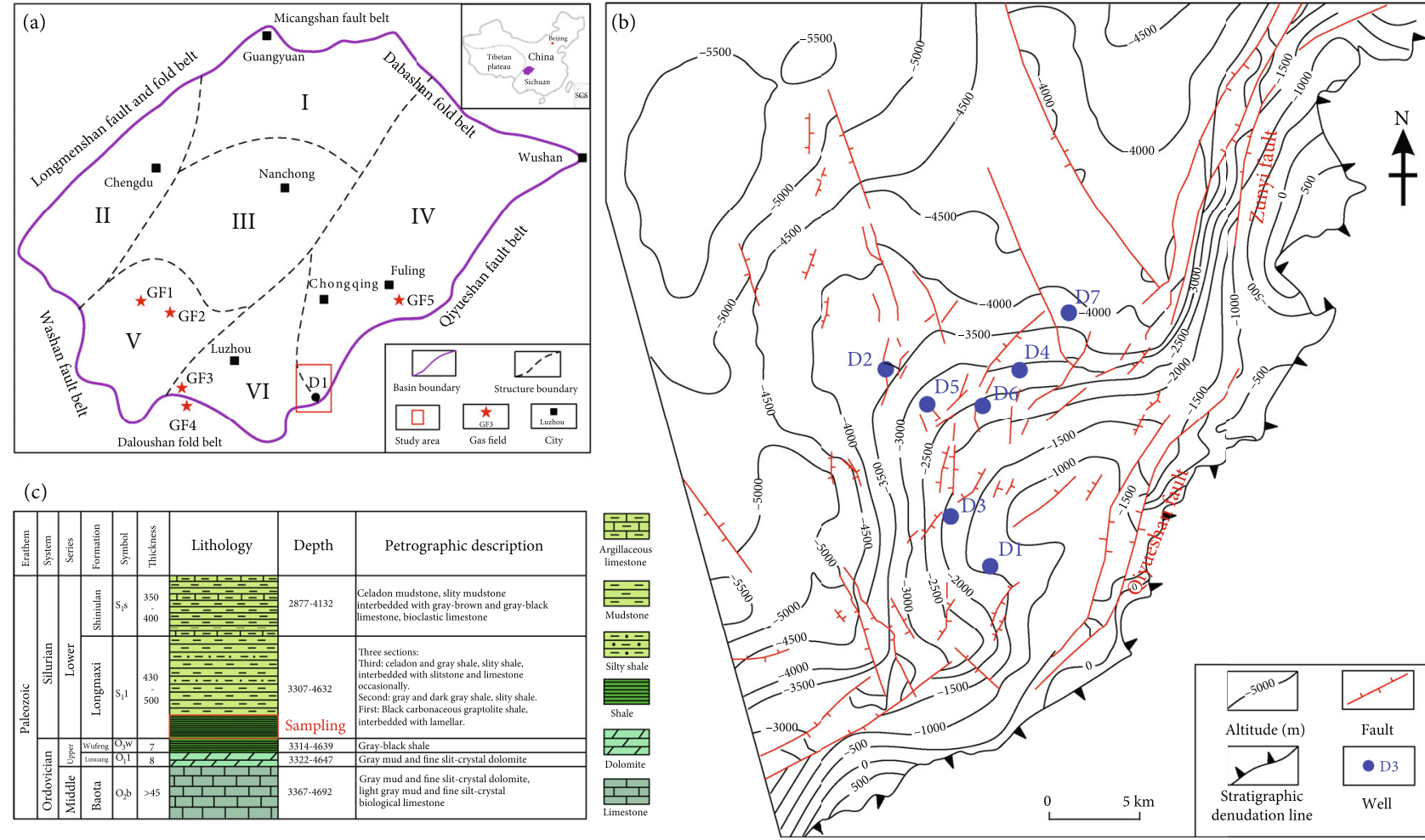

FIgure 1: (a) Tectonic distribution of Sichuan Basin (I: low gentle tectonic of North Sichuan; II: low steep tectonic of West Sichuan; III: gentle tectonic of Middle Sichuan; IV: high steep tectonic of East Sichuan; V: low steep tectonic of Southwest Sichuan; VI: low steep tectonic of South Sichuan; GF1: Weirong gas field; GF2: Weiyuan gas field; GF3: Changning gas field; GF4: Zhaotong gas field; GF5: Fuling gas field). (b) Buried depth map and sampling location of Longmaxi shales in Dingshan field. (c) The formations and sampling target (according to Lu et al. [42] and Zhu [43] modified).

rocks in a dispersive or blocky way, and its morphology largely depended on the shape of the cavity that is occupied by migrabitumen. Organic petrologists have proposed to classify organic matter in shale rocks according to its distribution characteristics, such as occurrence, distribution location, reflectivity, fluorescence, and its relationship with authigenic minerals [15-20]. According to the contact relationship between organic matter and minerals in the mud shale, Zhao et al. [21] and Loucks et al. [3] put forward the petrography logo for distinguishing the migrated solid organic matter and the organic matter in situ (including kerogen and some solid bitumens/pyrobitumens) in marine mud shale. And Liu et al. [22], Bai et al. [23], Zhang et al. [24], and Mastalerz et al. [25] demonstrated that the organic matter observed under SEM is primarily distributed around autogenous silicates or grows with clay minerals. With the morphology, internal structure, and distribution of organic matter, Zhang et al. [6] recognized bitumen, spherical kerogen, algal debris, bacteria-like organic matter, and graphite.

The classification and influencing factors of different organic pores in shale are complex, and no unified understanding had been achieved. The pores located in organic matter is further divided based on maceral type, including biological pores, gas pores, bitumen spherical pores, mold pores, bubble-like organic pores, and honeycomb organic pores [22-24]. Researchers had found that the development of organic matter pores was affected by organic matter con- tents, organic matter types, thermal evolution degrees, organic matter occurrence states, mineral compositions, diagenesis, and formation pressure coefficient [3, 4, 26-30]. At present, the effect of thermal evolution degree of organic matter on the development of organic pores is mainly studied [31-36]. Yang et al. [37] studied the organic pores of the lower Silurian Longmaxi formation shale with different thermal maturities in Sichuan Basin and pointed out that, for the organic matter of the same macular component, the number of organic matter pores in the samples shows a monotonically increasing trend with the increase of maturity. Meanwhile, the stage of late high maturity to early overmaturity is the main periods for the development of organic pores in the Longmaxi shale formation. However, exploration and development in different areas of southern Sichuan proved that the number and morphology of pores in rich organic matter shales in the lower Longmaxi formation are greatly different from the stage of late high maturity to early overmaturity [34], and the understanding of the differential development characteristics and controlling factors of organic matter pores under different preservation conditions is not clear, which is urgent to carry out related research. In this study, different organic matter types and pore distribution characteristics such as pore size distribution, shape coefficient, and fractal dimension, were quantitatively characterized by Ar-ion polishing and field emission scanning electron microscopy (FE-SEM) and were then combined 
TABle 1: Porosities and mineral contents of samples.

\begin{tabular}{|c|c|c|c|c|c|c|c|c|c|c|c|}
\hline \multirow{2}{*}{ No. } & \multirow{2}{*}{ Depth (m) } & \multirow{2}{*}{ Formation } & \multirow{2}{*}{ TOC (\%) } & \multicolumn{8}{|c|}{ Mineral contents (\%) } \\
\hline & & & & Clay & Quartz & Feldspar & Calcite & Dolomite & Pyrite & Anhydrite & Siderite \\
\hline$\overline{\mathrm{D} 1}$ & 2155.02 & Longmaxi shales & 4.68 & 21.89 & 55.33 & 4.56 & 4.44 & 6.56 & 5.33 & 1.71 & 1.00 \\
\hline D2 & 4398.00 & Longmaxi shales & 4.17 & 34.96 & 39.94 & 5.05 & 8.25 & 7.74 & 3.79 & 0.27 & l \\
\hline D3 & 2413.90 & Longmaxi shales & 4.73 & 29.33 & 51.84 & 6.02 & 3.18 & 7.54 & 2.09 & I & I \\
\hline D4 & 3965.74 & Longmaxi shales & 4.26 & 40.24 & 39.93 & 7.23 & 4.65 & 5.19 & 2.76 & l & 0.27 \\
\hline D5 & 4018.70 & Longmaxi shales & 3.79 & 37.33 & 38.62 & 5.46 & 3.35 & 7.89 & 6.41 & l & 1.14 \\
\hline D6 & 3447.17 & Longmaxi shales & 4.43 & 28.34 & 51.10 & 4.37 & 4.53 & 5.98 & 4.51 & 0.36 & 0.58 \\
\hline D7 & 4257.00 & Longmaxi shales & 3.90 & 32.32 & 41.13 & 3.15 & 11.11 & 5.89 & 4.77 & 0.36 & 0.49 \\
\hline
\end{tabular}

with energy spectrum analysis and image analysis technology. Based on this, the influence of formation pressure on the pore structure development of organic matter in shale was analyzed in the study area.

\section{Samples and Methods}

2.1. Geological Setting. Dingshan field is located at the junction of Qijiang of Chongqing and Xishui and Tongzi of Guizhou and is structurally located in the southeast of a fold belt in eastern Sichuan and the northwest of the Qiyueshan fault zone. It has experienced tectonic uplift and burial during the Caledonian period that led to folding and faulting in Yanshan-Himalayan.

Dingshan tectonics is mainly influenced by the Yanshan and middle Himalayan movements. After the late Himalayan movement, tectonic compression and uplift denudation dominated, and folds and faults developed in the whole study area. Because of the influence of Huayingshan fault, Qiyueshan fault, and Daloushan fault, the present structure of Dingshan field is a troughed fold composed of a series of NE and NNE trending high and steep anticlines and fault zones [38], and the overall shape on the plane is NE-SW nose-shaped anticline (Figure 1). The bedding of the northwest flank of the fracture back slope is steeply dipping, with stratigraphic dips mostly above $15^{\circ}$, and is cut by the Qiyueshan fault and associated fractures; the bedding of the northeast flank is relatively gentle, with stratigraphic dips mostly $10-15^{\circ}$ (Figure 1) $[39,40]$. The target strata of shale gas exploration in this area are the upper Ordovician Wufeng shales and the lower Silurian Longmaxi shales. Influenced by tectonic and two global transgressions during the upper Ordovician to the lower Silurian, the Sichuan Basin and its periphery formed a NE-opening shallow shelf sedimentary palaeogeographic pattern [41].

The strata in the study area are composed of Sinian, Cambrian, Ordovician, Silurian, Permian, Jurassic, Cretaceous, Paleogene, and Quaternary, among which the top of Sinian Dengying and Silurian and Permian Maokou have suffered different degrees of denudation due to the tectonic uplift [44]. The Sinian-middle Triassic is composed of marine deposits, while the upper Triassic-Eocene is composed of continental clastic rocks. The whole WufengLongmaxi shales were deposited in the favorable sedimentary facies zone of the deep-water shelf, and the lithology is dominated by gray-black and black carbonaceous mudstone or/and shale with rich organic matter, which is the main shale gas enrichment zone in the study area.

2.2. Sampling Materials. In this study, seven wells (D1 to D7) in the Dingshan field were studied (Figure 1 and Table 1). Among them, wells D1 and D3 are close to the Qiyueshan fault, located in the southeast of the Dingshan area near the edge of the Sichuan Basin (Figure 1(b)), with a burial depth of Longmaxi shales of about 2000-3000 m. Wells D2 and D4-D7 are far away from the Qiyueshan fault, located in the northwest of the Dingshan field close to the inner side of the Sichuan Basin, at a depth of more than $3000 \mathrm{~m}$ [45]. At present, the interpretation of shale gas well drilling in the study area showed that shales with TOC $>2 \%$ are concentrated at the bottom of Wufeng-Longmaxi formation, with a continuous thickness over than $30 \mathrm{~m}$ in each well $[40,46]$. Seven shale samples from the bottom of Longmaxi shales across wells D1 to D7 were collected in the Dingshan field.

2.3. Methods. Organic carbon content is measured by using the RJXWK-1 carbon-sulfur analyzer according to the total organic carbon (TOC) test standard in sedimentary rocks (GB/T 19145-2003). Firstly, the samples are ground until the particle size is less than $0.2 \mathrm{~mm}$, and samples of 0.01 $1.00 \mathrm{~g}$ are weighed and put into a porcelain crucible. Then, slowly add excessive dilute hydrochloric acid solution (the volume of dilute hydrochloric acid is bigger than $3 \mathrm{~mL}$ and must completely cover the sample), and heat it in a water bath (temperature controlled at $60-80^{\circ} \mathrm{C}$ ). Note: the sample dissolution time must be more than 2 hours until the reaction is complete. Finally, the acid-treated samples are placed in the porcelain crucible on the suction strainer and washed to neutral with distilled water. The porcelain crucible containing the samples is dried and burned in a high-temperature oxygen stream to convert the total organic carbon into carbon dioxide. The total organic carbon content is determined by an infrared detector.

The thermal maturity of organic matter is measured through the Axio Scope A1 polarized light microscope with MSP400 spectrophotometer according to the vitrinite reflectance test standard in sedimentary rocks (SY/T 5124-2012). In the test, samples were first crushed to $0.5 \sim 1.0 \mathrm{~mm}$ in size, and $10 \sim 20 \mathrm{~g}$ is taken for reserve by shrinkage method. 
Put about $5 \mathrm{~g}$ of samples and epoxy resin into a round mold with a diameter of $25 \mathrm{~mm}$ in a ratio of $1: 1$, stir evenly and add epoxy resin to it after a little curing to a height of about $12 \mathrm{~mm}$, and take out the light sheet for testing after $24 \mathrm{~h}$. According to the actual reflectivity of the samples, the standard samples of Yttrium Aluminum Garnet (Ro $=0.90 \%)$, Gadolinium Gallium Garnet (Ro $=1.72 \%)$, Cubic Zirconia $(\mathrm{Ro}=3.17 \%)$, and Diamond $(\mathrm{Ro}=5.21 \%)$ were used for calibration before the test.

The types of organic matter were determined under light microscope observations and fluorescence according to the method of kerogen maceral identification and classification (SY/T 5125-2014).

Organic matter pores were investigated by Ar-ion polishing, FE-SEM, and energy spectrum analysis. The analysis instruments are American Gaton (polishing), ZEISS sigma 300 (scanning electron microscopy, SEM), and Bruker Quantax 200 (energy dispersive spectroscopy, EDS). The resolution is $0.8 \mathrm{~nm}(15 \mathrm{keV})$ in the secondary electron mode and $0.6 \mathrm{~nm}(15 \mathrm{keV})$ in the transmission electron mode for ZEISS sigma 300 . Samples are firstly cut vertical to the shale bedding into $10 \mathrm{~mm} \times 10 \mathrm{~mm} \times 3 \mathrm{~mm}$, and the selected polishing surface is polished by Ar-ion and observed by SEM. Pore parameters such as diameter, shape coefficient, and fractal dimension were analyzed by means of ImageJ image software.

Fillippone formula is a formation pressure calculation method independent of normal compaction trend line proposed by W.R. Fillippone based on seismic, well logging and drilling data in the Gulf of Mexico and other areas, which is $P_{\mathrm{f}}=\left(v_{\max }-v_{i}\right) * P_{\mathrm{ov}} /\left(v_{\max }-v_{\min }\right) . P_{\mathrm{f}}$ is the pore pressure in formation, $\mathrm{MPa} ; v_{\min }$ is the formation acoustic velocity when the rock rigidity is close to zero, which is approximate to the pore fluid velocity, $\mathrm{m} / \mathrm{s} ; v_{\max }$ is the $\mathrm{P}$ wave velocity when the rock porosity is close to zero, $\mathrm{m} / \mathrm{s}$; $v_{i}$ is the seismic velocity of the $i$ layer, $\mathrm{m} / \mathrm{s}$; and $P_{\mathrm{ov}}$ is the overburden pressure, $\mathrm{MPa}$.

\section{Results}

3.1. Geochemical Characteristics. The TOC of the test samples is bigger than $3.5 \%$, with relatively high TOC content. Under optical microscope, the organic macerals are solid bitumen, mineral-bituminous groundmass, some animal debris, and algae (Figure 2). The solid bitumen shows clear morphology, but the mineral-bituminous groundmass itself has no fixed morphology and mostly cogrowing with inorganic minerals to form symbiote (Figures 2(a)-2(d)). Combined with the transmission electron microscope (TEM) observation, the animal debris in the samples mainly included graptolites and foraminifera, which were partially degraded in the deposition stage and partially transformed into amorphous dispersed organic matter and retained (Figures $2(\mathrm{c})-2(\mathrm{f})$ ). Some graptolite debris are distributed in rock matrix, and the particle size is larger than solid bitumen (Figures 2(c) and 2(d)).

The vitrinite reflectivities (Ro, \%) of seven samples were measured after sample preparation. The organic matter observed under the microscope is mainly bitumen, and the bitumen distributed in the clay mineral is greatly affected by mineral interference during measurement. Therefore, the bitumen with granular or angular shape distributed in the pore or mineral particle edge is selected, and the random reflectivity value $(\mathrm{Rb}, \%)$ of this kind of bitumen is tested (Figure 3 and Table 2). The results show that the random reflectance of this kind of bitumen is mainly distributed in the range of $2.54 \% \sim 2.97 \%$ (total number of measuring point $>156$ ), and vitrinite reflectance equivalence values were calculated according to different conversion formulas proposed in literatures [14, 47-50]. The thermal evolution degree (Ro, \%) of organic matter of the seven samples is mostly distributed in the range of $2.22 \%-2.55 \%$, depicting the (over-) mature stage of hydrocarbon generation.

3.2. Characteristics of Organic Matter. SEM observation has shown that micropores in the shale reservoir of Longmaxi shales for different organic matters have quite different distribution morphology and pore development characteristics. Based on the petrological and morphological distribution characteristics of different organic matters which were distributed in the matrix or independently, we proposed that organic matter can be divided into two categories: organic matter in situ and migrated organic matter. Most of the organic matter in situ is distributed in the shale matrix in blocks, and some of the organic matter is distributed in a curved shape. Besides, organic matter in situ is composed of algae, acritarchs, and plant debris (Figure 4), which are closely bound with mineral matrix. Pores were found in organic matters in situ, mostly in the form of isolated and randomly distributed pores (Figure 4(f)), some of them connected.

The morphology of migrated organic matter (i.e., solid bitumen) is irregular and is mostly cogrown within the matrix mineral filling between the mineral edges of silicates, clay minerals, or pyrite. Minerals and migrated organic matter are mixed, without clear boundary. Because of the strong plasticity of organic matter, part of migrated organic matter is strongly compacted during diagenesis, and its morphology is primarily determined by the distribution morphology of surrounding symbiotic minerals. Clay minerals have small particle size and poor crystal morphology; thus, the organic matter cogrowing with the clay minerals mainly developed in their intercrystalline pores and some of the organic matter is bent and deformed along with the clay minerals. Lu et al. $[28,51]$ studied the influence of clay minerals in shale on the occurrence state of organic matter and pointed out that the increase of clay mineral content, such as illite, positively correlates with the increase of organic matter storage space and the development of organic matter pores (Figures 5(a), 5(b), and 5(f)). The pore size of organic matter pores in the clay mineral lattice is large, and some of them were connected to form a series of pores which were mainly approximately elliptical, irregular, and cucurbitaceous (Figures 5(a) and 5(f)). Moreover, under microscopic observation, the main occurrence types of pyrite in the test samples were banded, framboidal, and cubic. The organic matter developed between the crystals in framboidal pyrite or at the edge of framboidal pyrite (Figures 5(c) and 5(d)). Organic matter pores are mostly approximately elliptical and irregular and partially connected to each other. 


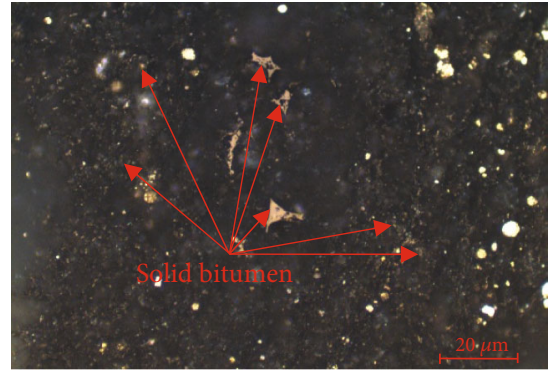

(a)

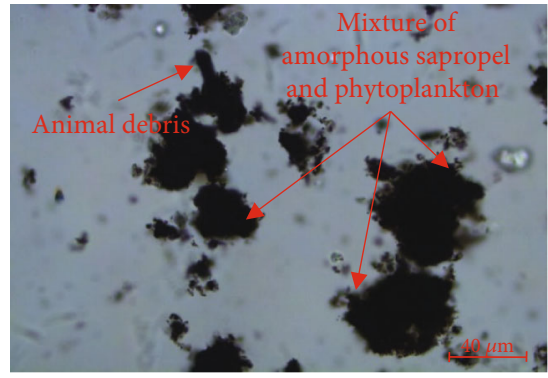

(c)

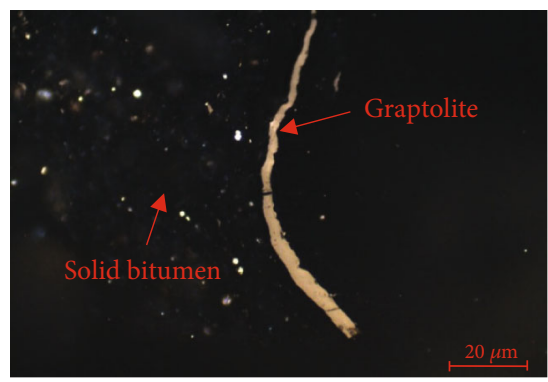

(e)

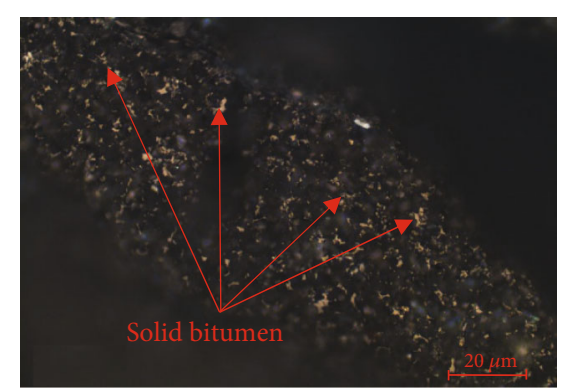

(b)

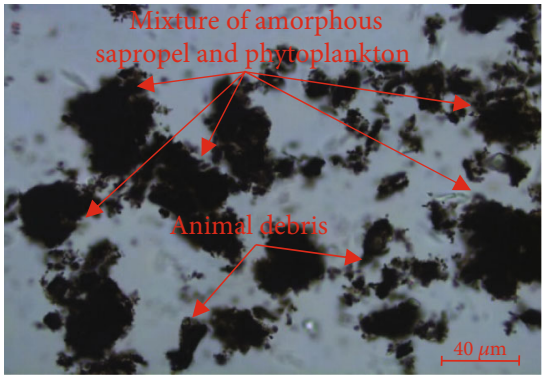

(d)

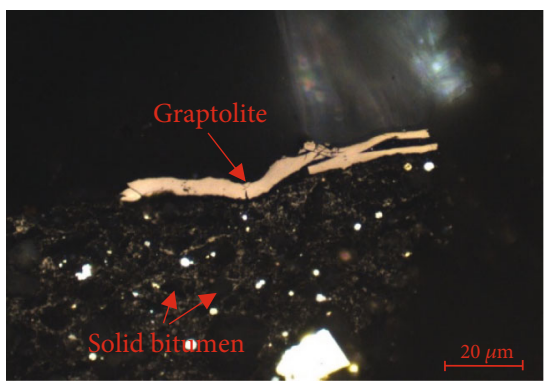

(f)

Figure 2: Organic matter macerals under microscope ( $(c, d)$ animal debris and mixture of amorphous sapropel and phytoplankton observed under reflected light; ( $a, b, e, f)$ graptolite and some solid bitumen observed under transmission light).

3.3. Characteristics of Organic Matter Pore Development in Different Wells. Not all organic matter has pores. As the carrier of organic pores, organic matter has various pore characteristics. Based on the above analysis, the mechanisms that led to pore development in different organofacies were different. To more accurately analyze these differences, a large number of SEM images were processed and analyzed. Pore numbers, median pore diameter, shape coefficient, and fractal dimension [33] were used to quantitatively characterize pores in different organic matter types (Table 3 ).

The pore diameter is defined as equivalent circle diameter. The equivalent circular diameter of narrow-long irregular pores can be expressed as $D=4 A / L=4 *(a * b) / 2 *$ $(a+b)=2 a * b /(a+b)$. $a$ and $b$ are the length and width of pore, respectively.

The shape coefficient is expressed as $F=4 \pi S / C^{2} . S$ and $C$ are the area and perimeter of pore cross section, respectively. If the shape coefficient is 1 , it means that the object is round.

The distribution ratio $(Q)$ of different types of organic matter is defined as the percentage of organic matter distribution area and total area on the SEM image. $Q=\left(\sum S_{\mathrm{OM}}\right)$ / $S_{\text {Total }} * 100 \% ; S_{\mathrm{OM}}$ is the sectional area of organic matter and $S_{\text {Total }}$ is the total area of the sample observed in the SEM image.

The fractal dimension is determined by the relationship between the pore number and pore size $(r)$ of different size pores in the sample. According to the fractal theory, when the pore size distribution in porous media has fractal characteristics, the relationship between the pore number and pore size $(r)$ exists as follows: $N(\geq r)=\int_{r}^{r_{\max }} f(r) d r=a r^{-D_{\mathrm{f}}} \cdot r_{\max }$ is the maximum pore size, $f(r)$ is the probability density function of pore size distribution, $a$ is constant, and $D_{\mathrm{f}}$ is the fractal dimension.

The pore size, shape coefficient, and fractal dimension of organic matter pores in different samples are shown in Table 3 and Figure 6 . The results outline that pores in wells D1 and D3 are mainly micropores and mesopores, with a relatively small size, mainly within the range from 5 to $50 \mathrm{~nm}$. Pores are primarily irregular and partially slit, with a mean shape coefficient of 0.674 and 0.554 , respectively. In wells D2 and D4 to D7, the organic matter pores are mainly mesopores, with a pore size mainly between $8 \mathrm{~nm}$ and $80 \mathrm{~nm}$. Pores are mainly round and elliptical, with a mean shape coefficient larger than 0.801 . 

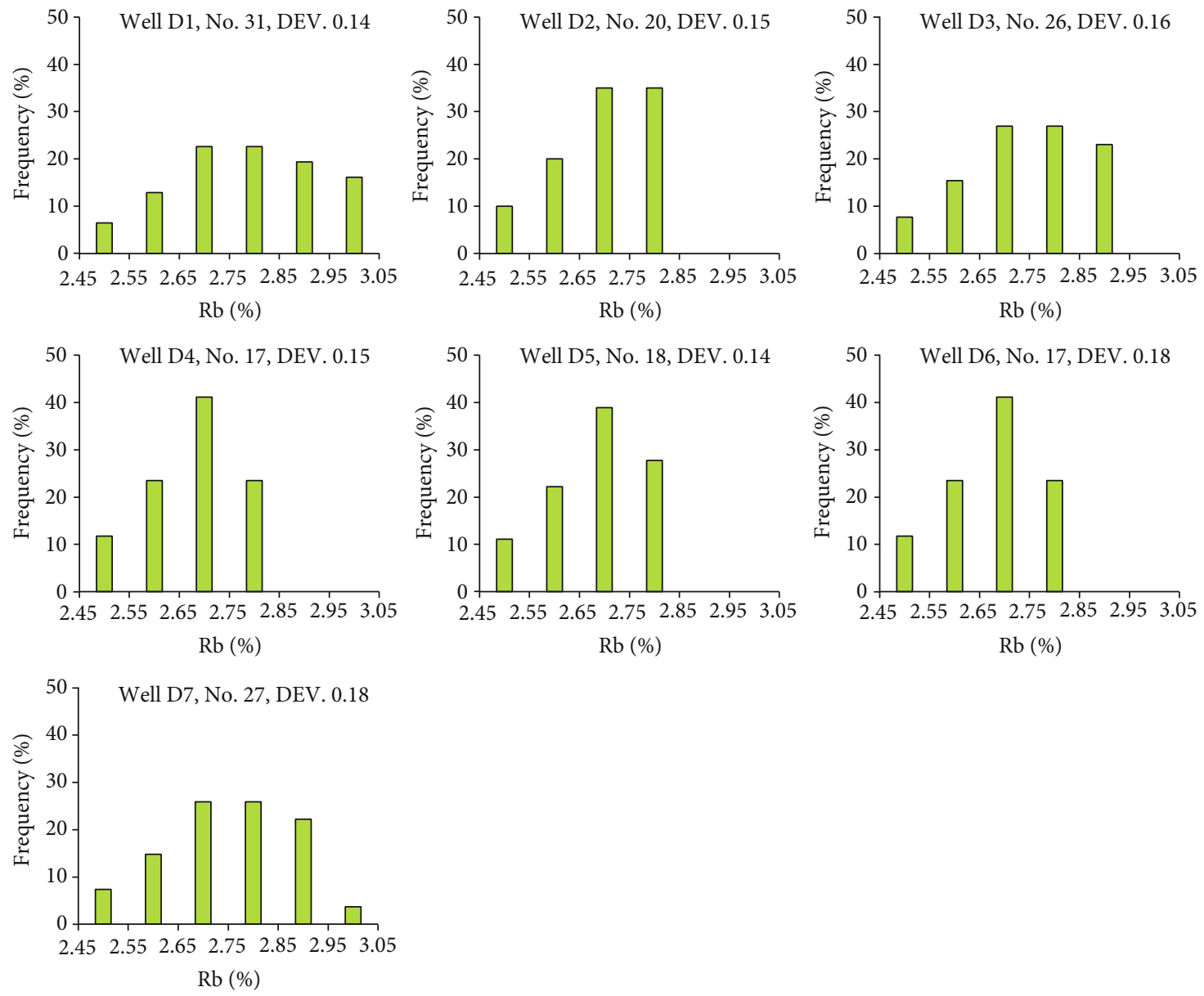

FIGURE 3: Random reflectance distribution of solid bitumen in different samples.

TABLE 2: Solid bitumen random reflectance and equivalent vitrinite reflectance in seven samples.

\begin{tabular}{ccccccccccc}
\hline No. & Depth $(\mathrm{m})$ & Ave. Rb (\%) & Measuring point & St.D. & Ave. Ro (\%) & EqV Ro-1 & EqV Ro-2 & EqV Ro-3 & EqV Ro-4 & EqV Ro-5 \\
\hline D1 & 2155.02 & 2.79 & 31 & 0.14 & 2.41 & 2.17 & 2.12 & 2.93 & 2.20 & 2.64 \\
D2 & 4398.00 & 2.84 & 20 & 0.15 & 2.45 & 2.20 & 2.16 & 2.98 & 2.23 & 2.69 \\
D3 & 2413.90 & 2.56 & 26 & 0.16 & 2.24 & 2.02 & 1.98 & 2.72 & 2.03 & 2.43 \\
D4 & 3965.74 & 2.54 & 17 & 0.15 & 2.22 & 2.00 & 1.97 & 2.71 & 2.01 & 2.41 \\
D5 & 4018.70 & 2.97 & 18 & 0.14 & 2.55 & 2.29 & 2.24 & 3.10 & 2.33 & 2.81 \\
D6 & 3447.17 & 2.88 & 17 & 0.18 & 2.48 & 2.23 & 2.18 & 3.02 & 2.26 & 2.73 \\
D7 & 4257.00 & 2.76 & 27 & 0.18 & 2.39 & 2.15 & 2.11 & 2.91 & 2.17 & 2.62 \\
\hline
\end{tabular}

Notes: EqV Ro-1 = 0.3364 + 0.6569Rb [47]; EqV Ro-2 = 0.4 + 0.618Rb [14]; EqV Ro-3=0.376 + 0.917Rb [48]; EqV Ro-4 = 0.16 + 0.73Rb [49]; EqV Ro-5 = $0.0278+0.9376 \mathrm{Rb}[50]$.

The linear slope of the plot $\ln N(r)$ vs. $\ln r$ is utilized to calculate the fractal dimension, which mainly ranged from 1.1 to 1.8 (Figure 7 ). In the SEM image, the distribution ratio of migrated organic matter is calculated as the percentage of organic matter distribution area and total area. From the relationship between the fractal dimension and the migrated organic matter contents, it could be observed that the higher the migrated organic matter contents, the more developed the organic matter pores, the more complex the pore morphology, and the higher the fractal dimension (Figure 8).

\section{Discussion}

Seven samples selected in this study are located in the same tectonic and have the same geological conditions. They are all in the deep-water shelf sedimentary environment, and the TOC contents are mostly above 3.5\%. The brittle mineral contents (quartz + feldspar) are between $40 \%$ and $55 \%$ (Table 1). The main types of organic matter are sapropelic, with the thermal evolution of overmature (Ro $>2.0 \%)$. The organic matter generally produces a lot of hydrocarbon and has similar geological evolution process. However, the 


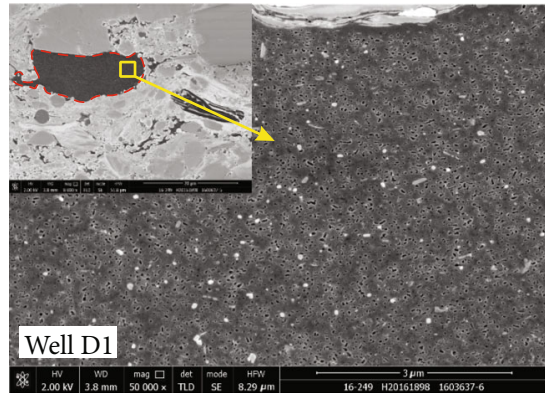

(a)

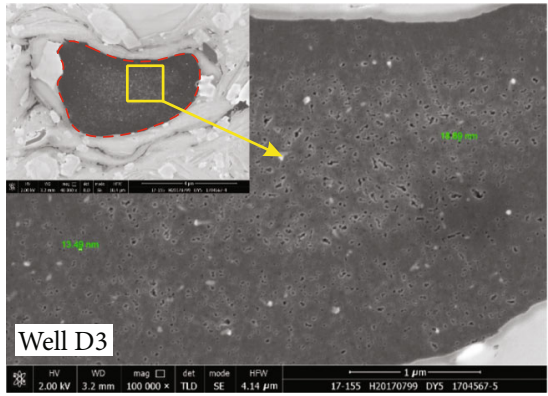

(c)

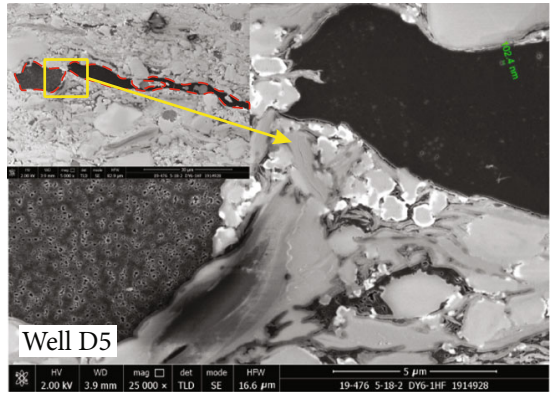

(e)

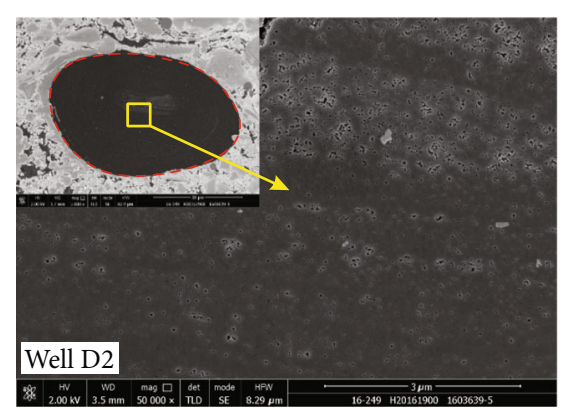

(b)

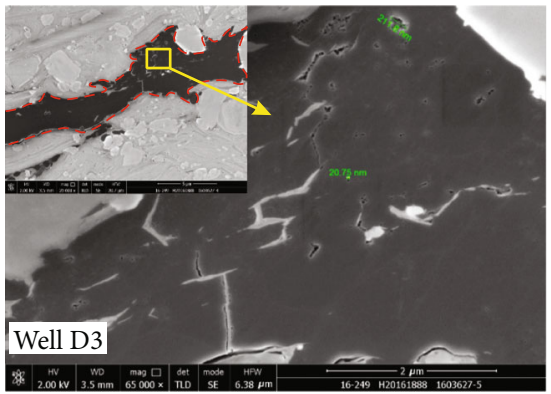

(d)

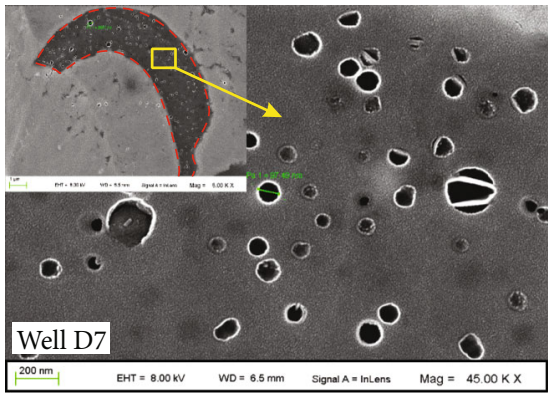

(f)

FIGURE 4: Characteristic of organic matter in situ and their organic matter pores in Longmaxi formation shale in Dingshan field under SEM ((a, c, f) acritarch; (b) algae; (d) plant debris; (e) graptolite debris).

porosity of different samples varies greatly. The average porosity of wells D2 and D4-D7 is relatively high, with an average of $5.49 \%$, but the porosities of wells D1 and D3 are significantly reduced, with the porosity of $4.02 \%$ and $4.13 \%$, respectively. Meanwhile, there are some differences in the number, size, and morphology of organic pores in different wells, which may be caused by the difference of formation pressure in different areas. So the influences of tectonic movement and formation pressure on the development of organic matter pores are mainly analyzed.

4.1. Formation Pressure Characteristic. Chen [52] pointed out that the formation pressure of Longmaxi shales in the study area was mainly affected by tectonic compression and fault distribution. Dingshan field is located in the transition from the trough-type fold belt in the west of Hunan and Hubei to the barrier-type fold belt in the east of Sichuan, which is a thrust nappe tectonic belt controlled by the Qiyueshan fault. Qiyueshan fault as the largest concealed basement fault in the Dingshan field, which is along the NE-trending to distribution, and after the basement thrust- ing of compresso-shear, remolding of Guizhou plate, and differential uplifting in Himalayan, the basement thrust occurred under the NE-trending thrust and formed strong fold deformation in Yanshanian. Qiyueshan fault plays a decisive role in the tectonic framework of the study area, cutting through the Silurian shale and its roof and floor and controlling the scale of fracture development [43]. According to the analysis of burial history and hydrocarbon generation history of wells D1 and D2 (Figure 9) [53], the Longmaxi formation shale showed rapid depositing during the middle-late Silurian. In Devonian to Carboniferous, it is continuously uplifted, but the uplifted amplitude is small and the buried depth is shallow, and after reaching the hydrocarbon generation threshold in early Devonian, it is always in the low maturity stage. After the early Permian, with the rapid increase of depositing rate, the burial depth and maturity of shale increased rapidly. In the early Triassic, the shale reached the peak of oil generation. In the early Jurassic, the shale rapidly entered the dry gas stage. In the early Cretaceous, with the burial depth reaching the maximum, the formation pressure reached the peak. The fluid 


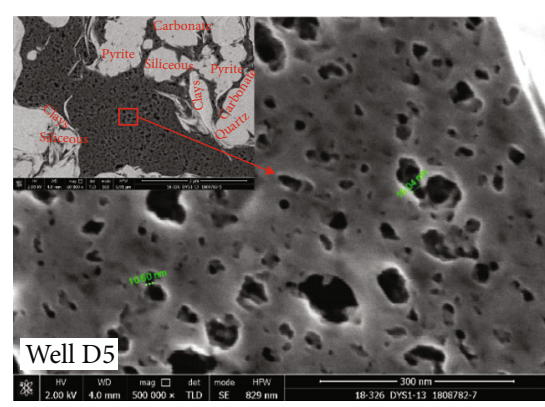

(a)

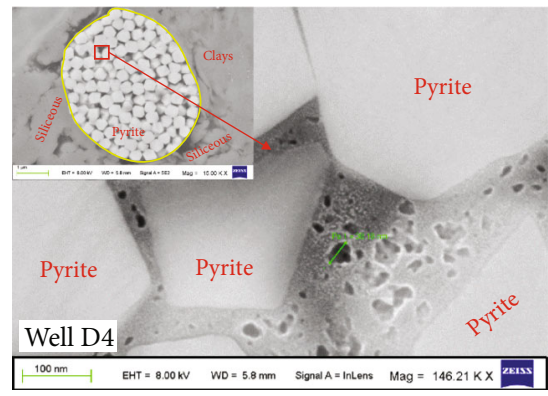

(c)

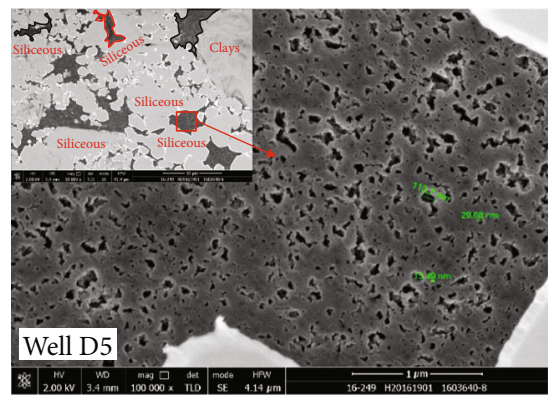

(e)

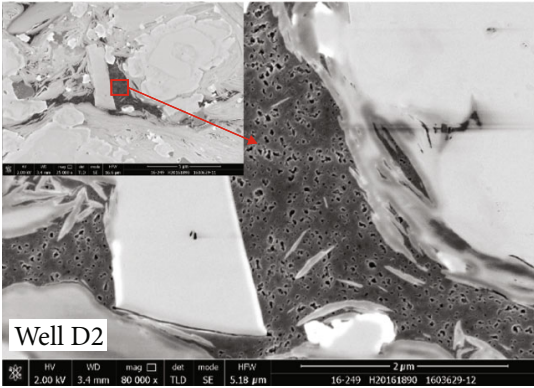

(b)

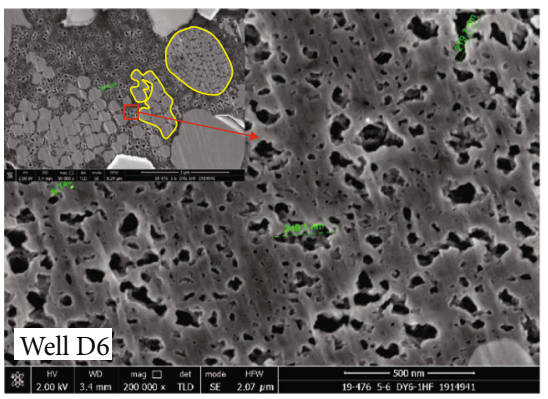

(d)

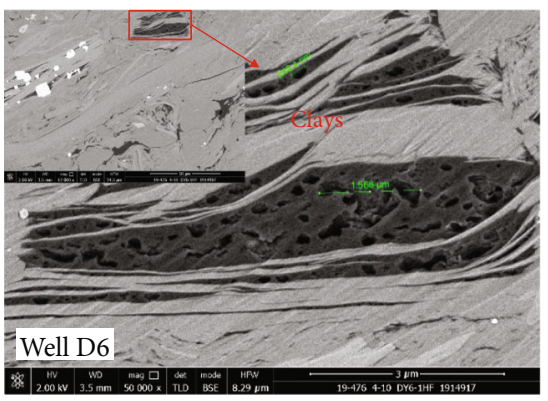

(f)

FIGURE 5: Characteristic of migrated organic matter and their organic matter pores in Longmaxi formation shale in Dingshan field under SEM. (a, b) Migrated organic matter and its organic matter pores between silicate particles. (c) Migrated organic matter and its organic matter pores in the intercrystalline pores between pyrite monocrystals. (d) Migrated organic matter and its organic matter pores in the interparticle pores between framboidal pyrite and surrounding minerals. (e) Migrated organic matter and its organic matter pores between particles. (f) Migrated organic matter and its organic matter pores in the interparticle pores between clay minerals.

TABLE 3: The results of pore development density, shape coefficient, and fractal dimension in different wells.

\begin{tabular}{|c|c|c|c|c|c|c|c|}
\hline Parameters & D1 & D2 & D3 & D4 & D5 & D6 & D7 \\
\hline $\begin{array}{l}\text { Development density } \\
\text { (unit/ } \mu \mathrm{m}_{2} \text { ) }\end{array}$ & 0.010 & 0.037 & 0.003 & 0.015 & 0.036 & 0.020 & 0.036 \\
\hline \multirow{2}{*}{ Shape coefficient* } & 0.674 & 0.801 & 0.554 & 0.829 & 0.884 & 0.786 & 0.922 \\
\hline & $\overline{0.112-0.876}$ & $\overline{0.349-0.927}$ & $\overline{0.074-0.779}$ & $\overline{0.248-0.936}$ & $\overline{0.376-0.954}$ & $\overline{0.321-0.945}$ & $0.483-0.987$ \\
\hline Fractal dimension & 1.176 & 1.511 & 1.108 & 1.488 & 1.222 & 1.585 & 1.776 \\
\hline
\end{tabular}

*Shape coefficient: average/(minimum - maximum).

compaction coupling model is selected to simulate the pressure evolution [54], and after the pressure in the Longmaxi formation shale reached the maximum in the late Cretaceous, the formation pressure decreased in different degree due to the influence of three stages of tectonic uplift (including rapid uplift from early Cretaceous to the end of late Cretaceous, slow uplift from the end of late Cretaceous to
Oligocene, and rapid uplift since Oligocene) and denudation and the development of Qiyueshan fault zone.

The distances between different wells and Qiyueshan fault and the fracture degree and the denudation degree of strata are different. By analyzing the development of Longmaxi formation shale in the Dingshan field, Zhong [55] pointed out that since the Yanshanian tectonic movement, 


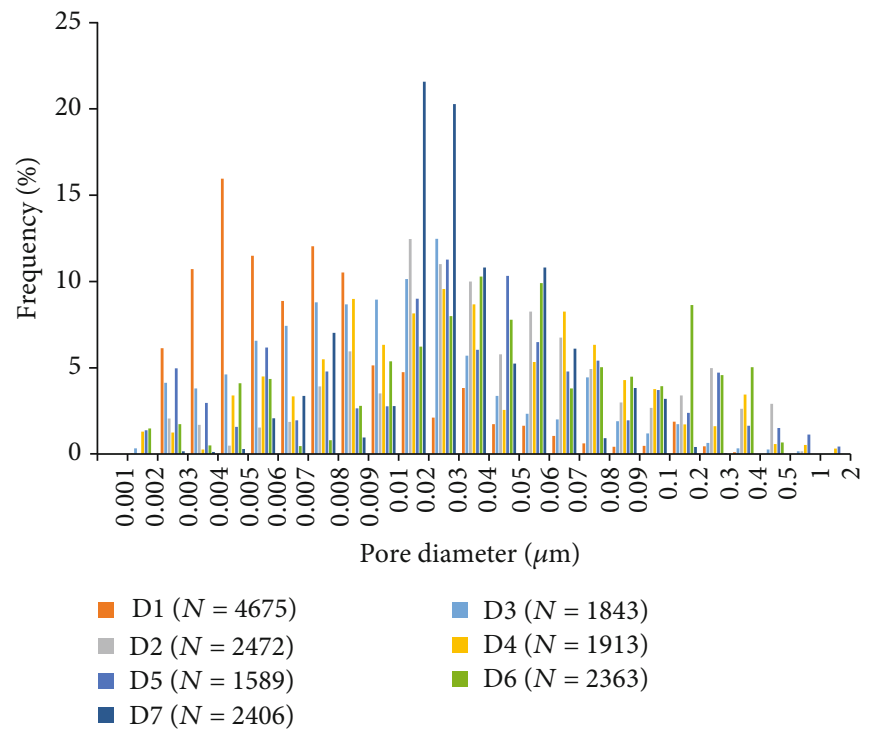

Figure 6: Pore size distribution of organic matter in the analyzed shales of wells.
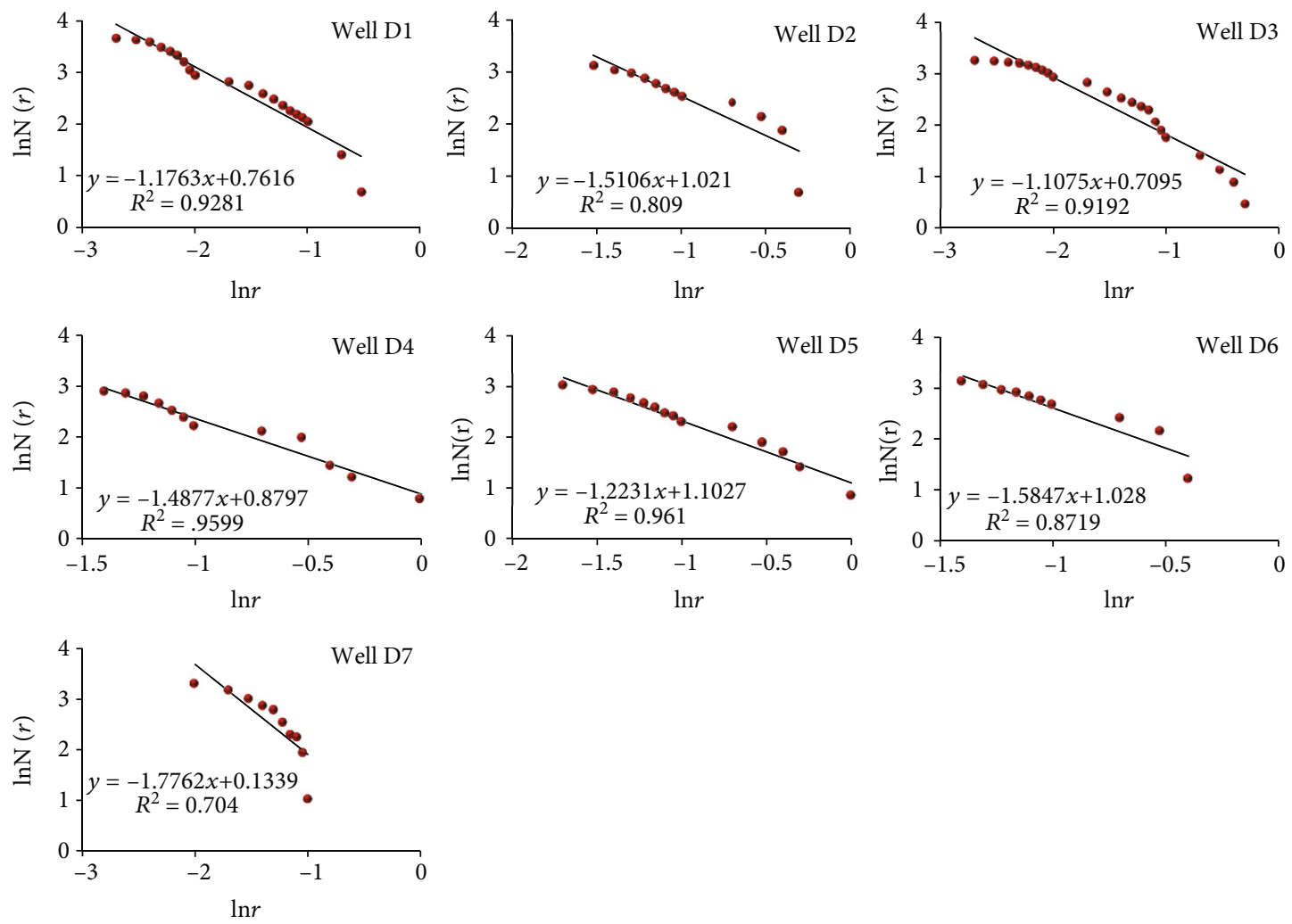

FIGURE 7: $\ln N(r)-\ln r$ of wells D1-D7.

the region of wells D1 to D3 near the Qiyueshan fault has been uplifted for a long time (about $85 \mathrm{Ma}$ ) and a large uplift height (about $2800 \mathrm{~m}$ ), and the sealing capability of fractures and faults is poor. However, the region of wells D2 to D7 far away from the Qiyueshan fault has a low degree of tectonic reconstruction and good sealing capability of fractures and faults. Generally, the larger the fault displacement, the more developed the nearby fractures and the greater the degree of formation pressure relief [56]. The variation of upliftdenudation period and denudation thickness will have a significant influence on the physical properties of shale reservoirs, hydrocarbon generation and expulsion behavior, and the formation and maintenance of overpressure state [57].

From Figure 10, wells D1 and D3 are located in the southern section of Dingshan fault-nose anticline, $8.5 \mathrm{~km}$ and $14.7 \mathrm{~km}$ away from Qiyueshan fault, respectively, and 


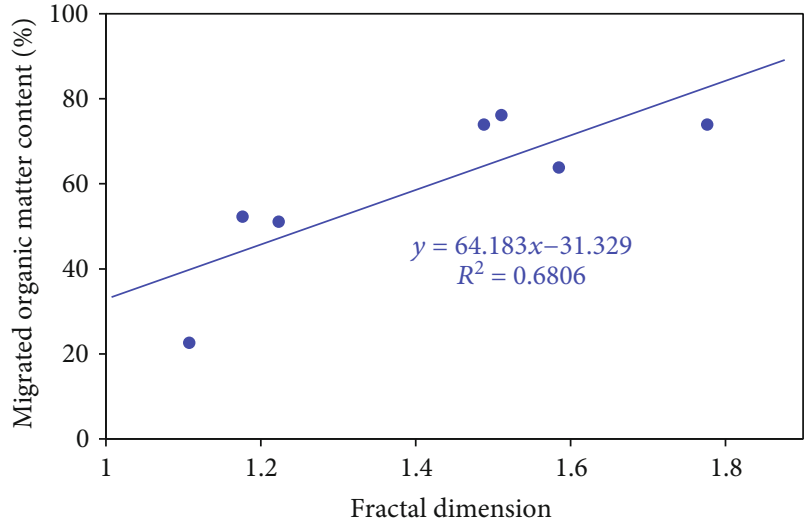

Figure 8: The relationship between the fractal dimension and migrated organic matter contents.

the fault displacement near well D1 is large, generally more than $100 \mathrm{~m}$, and high-angle fractures are developed (Figures 1 and 10). Wells D2 and D4 are located in the slope zone and syncline of Dingshan structure, with relatively stable structure, $17.4 \mathrm{~km}$ and $13.1 \mathrm{~km}$ away from the outcropping denuded area of Longmaxi shales and $23.3 \mathrm{~km}$ and $25 \mathrm{~km}$ away from Qiyueshan fault. The fault displacement around well D2 is relatively small, generally less than $60 \mathrm{~m}$. They are less influenced by the superposition of tectonic stress and only form NW-SE trending fractures, with no high-angle fractures in the roof $[43,46]$.

Fillippone formula is employed to predict the present pressure of Longmaxi shales by using pseudoacoustic seismic inversion [40]. Results indicated that the pressure coefficient gradually increased from southeast to northwest. Pressure coefficient refers to the ratio of original formation pressure to hydrostatic column pressure, based on the data collected from shut-in pressure buildup test of wells D1 to D5 in Dingshan field (Table 4 and Figure 10). In the shutin pressure recovery calculation of well $\mathrm{D} 2$, the pressure at the converted formation depth of $4398 \mathrm{~m}$ is $80.80 \mathrm{MPa}$, and the pressure coefficient is 1.82 . It indicates that the pressure systems of shale reservoir in wells D1 and D3 are normal, but are high-ultrahigh pressure system (the formation pressure coefficient is greater than 1.2) in wells D2, D4, and D5.

\subsection{Influence of Pressure System on Organic Matter Pore} Characteristics. By comparing the pressure coefficient and gas production of some shale gas reservoirs (Table 5), it is shown that the pressure coefficient positively correlates with shale gas production [58-60]. There is a certain correlation between gas content and fluid pressure coefficient of shale reservoir, that is, the greater the pressure coefficient is, the greater the gas production is.

As an important part of shale pore system, organic matter pores are formed in the process of shale hydrocarbon generation and evolution. They are the traces left by shale gas generation, diffusion, and accumulation and also the embodiment of gas generation and storage capacity of shale reservoir. Taking thermal maturity (Ro, \%) as the main classification index, the evolution of organic matter pores in
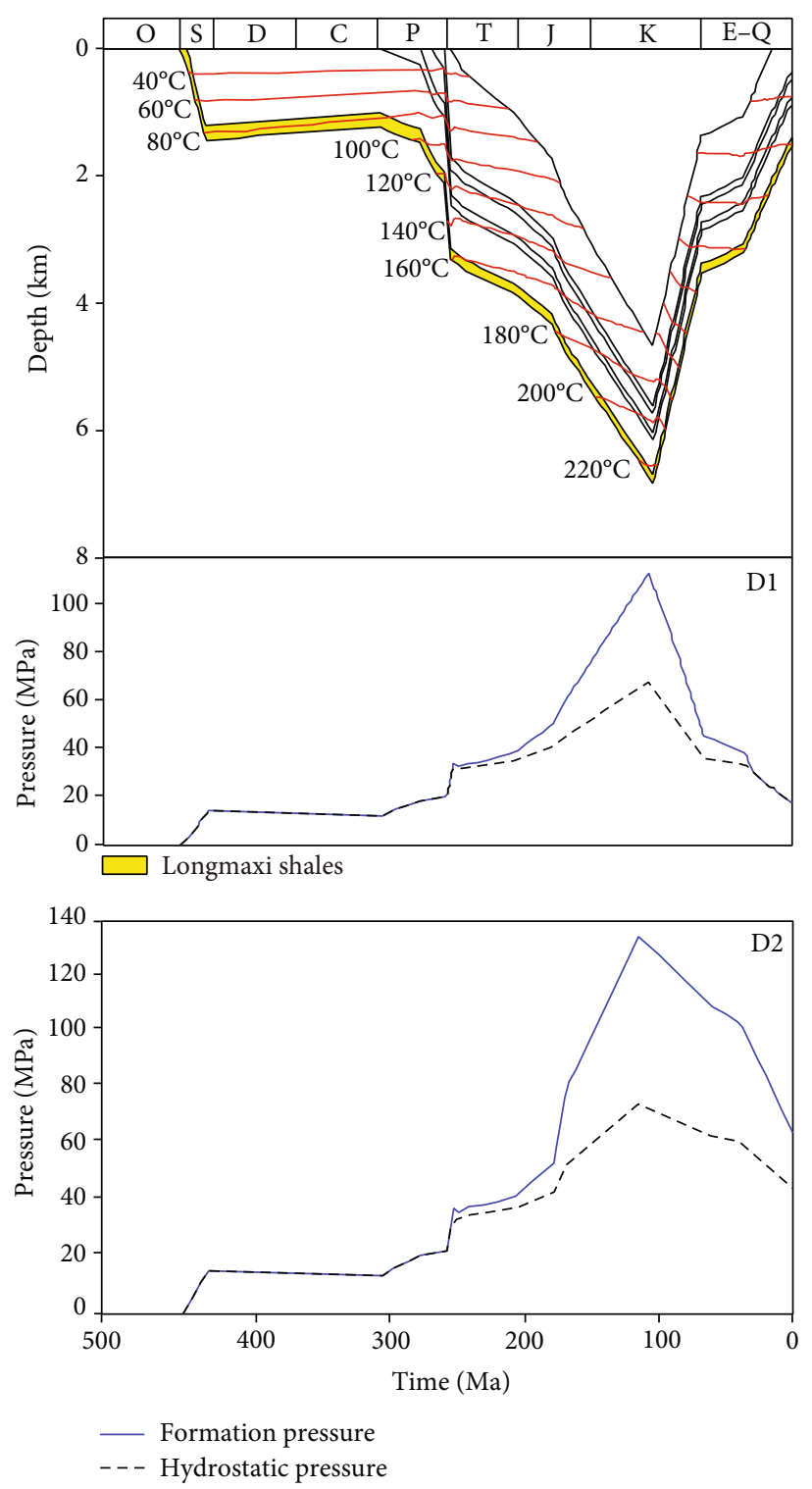

Figure 9: The "burial-hydrocarbon generation-uplift" evolutionary framework of wells D1 and D2 (according to Qiu et al. [53] modified) (O: Ordovician; S: Silurian; D: Devonian; C: Carboniferous; P: Permian; T: Triassic; J: Jurassic; K: Cretaceous; E: Paleogene; Q: Quaternary).

shale can be divided into four stages, including im- and low-maturity stage $(\mathrm{Ro}<0.7 \%)$, mature stage $(0.7 \%<$ Ro $<1.3 \%)$, high- and overmaturity stage $(1.3 \%<$ Ro $<3.5 \%)$, and metamorphic stage $(\operatorname{Ro} \geq 3.5 \%)$ [61, 62]. Crude oil is formed by early pyrolysis of kerogen in the im- and lowmaturity stage and mature stage. With the increase of thermal evolution degree, part of the residual crude oil in the shale cracked into natural gas with the rise of temperature and pressure, and the generated natural gas initially existed in the form of tiny gas cores. With the continuous cracking and separation of the light components in the crude oil, the crude oil began to be transformed into bitumen, and the amount of cracking gas increased, accompanied by the formation of a large number of organic pores. The morphology 


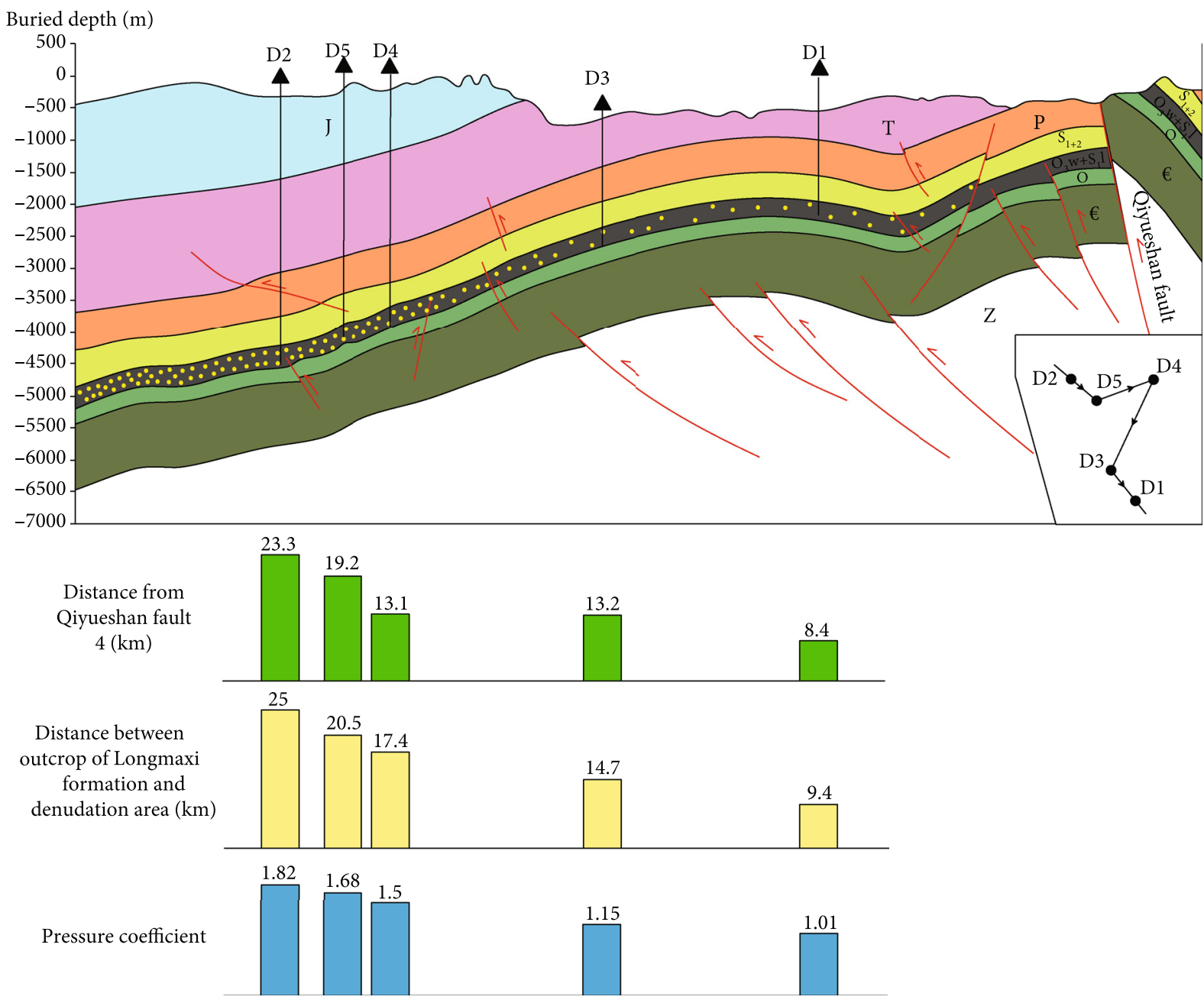

Figure 10: The profile map and formation pressure coefficient of wells D1 to D5 (modified from Zhu [43]) (Z: Sinian; €: Cambrian; O: Ordovician; S: Silurian; P: Permian; T: Triassic; J: Jurassic).

TABLE 4: Formation pressure and geothermal temperature of Longmaxi shales in Dingshan field.

\begin{tabular}{lccccc}
\hline Well & $\begin{array}{c}\text { Depth } \\
(\mathrm{m})\end{array}$ & $\begin{array}{c}\text { Pressure } \\
(\mathrm{MPa})\end{array}$ & $\begin{array}{c}\text { Pressure } \\
\text { coefficient }\end{array}$ & $\begin{array}{c}\text { Middle } \\
\text { formation } \\
\text { temperature } \\
\left({ }^{\circ} \mathrm{C}\right)\end{array}$ & $\begin{array}{c}\text { Geothermal } \\
\text { gradient } \\
\left({ }^{\circ} \mathrm{C} / 100 \mathrm{~m}\right)\end{array}$ \\
\hline D1 & 2155.02 & 22.80 & 1.01 & 81 & 2.83 \\
D2 & 4398.00 & 80.80 & 1.82 & 145 & 2.84 \\
D3 & 2413.90 & 26.00 & 1.15 & 90 & 2.90 \\
D4 & 3965.74 & 58.30 & 1.5 & 139 & 3.00 \\
D5 & 4018.7 & 66.10 & 1.68 & 140 & 2.99 \\
\hline
\end{tabular}

Note: the average surface temperature is assumed to be $20^{\circ} \mathrm{C}$.

of organic pores is from the initial formation of microcracks in the organic matter, to the formation of round or elliptical honeycomb pores, and then to the interconnection of honeycomb pores to form aggregates. That is to say, without the influence of formation pressure, with the increase of thermal evolution degree, organic pores are mostly round or elliptical and part of them is interconnected.
For example, in well D3, the Longmaxi formation is characterized by large denudation thickness and relatively close proximity to the Qiyueshan fault, so the Longmaxi formation is more prone to slip deformation and pressure unloading, and the pressure relief intensity is high (with the present formation pressure coefficient of 1.15). Also, organic matter and organic matter pores in shale are deformed and contracted under lateral stress extrusion and pressure unloading, and organic matter is mostly distributed in band. Although the number of pores in the organic matter is large, the pore size is relatively small, about $10-25 \mathrm{~nm}$. The pore morphology is mostly long-narrow or oblate, and some organic pores gradually changed into oblate mesopores directionally (Figures 4(a) and 4(d)). These indicate that the organic pores suffer from strong compaction, causing the pore size to become smaller or even to disappear.

However, in well D7, the formation pressure evolution of Longmaxi formation is characterized by small denudation thickness, far away from Qiyueshan fault and low pressure relief intensity (the formation always maintains overpressure, and the present formation pressure coefficient is 1.58). Under SEM, a large number of banded, irregular, or 
TABle 5: Pressure coefficient and gas production of some shale gas formations $[58,60]$.

\begin{tabular}{lcccc}
\hline Formation & Location & Depth $(\mathrm{m})$ & Pressure coefficient & Gas production $\left(\times 10^{4} \mathrm{~m}^{3} / \mathrm{d}\right)$ \\
\hline Barnett & Fort Worth & $1980-2600$ & 0.99 & $5.4-6.2$ \\
Eagle Ford & Maverick & $1220-3650$ & $1.35-1.8$ & $14.2-28.7$ \\
Fayetteville & Arkoma & $305-2135$ & $1.38-1.84$ & 21 \\
Haynesville & East Texas & $3050-4000$ & $1.62-2.08$ & $27.6-54.5$ \\
Wufeng-Longmaxi & Jiaoshiba & $2200-4500$ & $1.5-2.0$ & $15-45$ \\
Wufeng-Longmaxi & Pengshui & $2000-3000$ & $0.9-1.1$ & $1-2.5$ \\
\hline
\end{tabular}

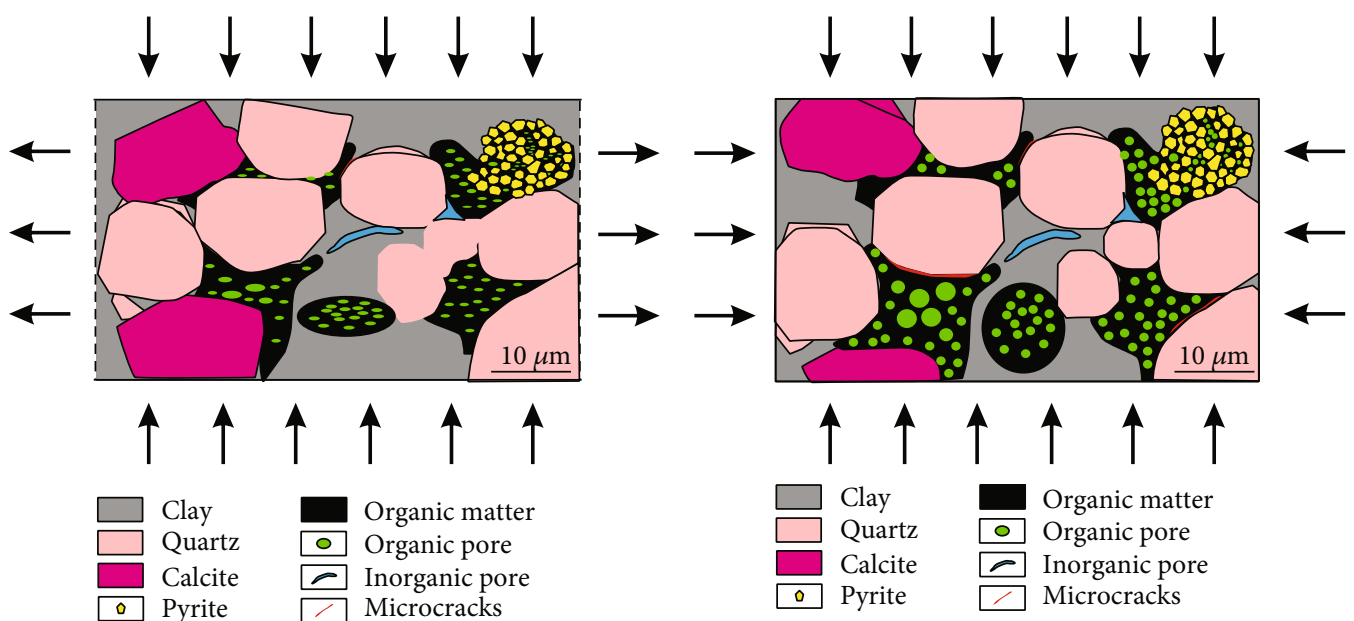

(a) Semiclosed system

(b) Closed system

FIGURE 11: Development mechanism of organic matter pores in different formation pressure systems.

lamellar organic matters were found between mineral particles. The organic matter pores in the triangular zone of some rigid mineral particles and the interlayer pores of some clay minerals developed. These organic matter pores were round or elliptical and partially irregular and slit (Figure 4(f)). Because of the protection of organic matter by inorganic minerals and other matrices, the morphology of organic matter pores is well protected, and some organic matter pores were large and interconnected. These indicate that the formation of overpressure hinders the normal compaction and preserves some organic pores with little morphological changes. Therefore, overpressure plays an important protective role in the preservation of organic matter pores in shale.

Shale gas is an unconventional resource that is generated and stored in the source rock without any migration. Shale gas forms in a physical-chemical system composed of inorganic minerals, organic matter, and formation fluids, which are associated with and mutually influenced by multiple processes [30]. In the process of diagenetic evolution, hydrocarbon generation from organic matter leads to the increase of pore fluid pressure in the formation, and with the increase of burial depth, the loading pressure of the overlying shale increases continuously. Under the influence of tectonic uplift, denudation, and fault, the loading pressure of the overlying shale changed, leading to the pressure relief of the shale reservoir in different degrees. Under the semiclosed environment, the strata are damaged greatly due to the influ- ence of tectonic uplift and fault, and the overburden pressure of shale is greater than the pore fluid pressure, which leads to the compaction of organic matter and the change of morphology. The organic pores are compressed, the pore size decreases, and some pores even close and disappear (Figure 11(a)). However, under the closed environment, the strata are uplifted as a whole with little damage, and the overburden pressure of the shale is less than the pore fluid pressure, so part of the pressure formed during the cracking of organic matter can be maintained. The compaction of organic matter is small, and the morphology of organic pores is relatively round and the pore size is larger (Figure 11(b)), indicating that overpressure is an important protection for the preservation of organic matter pores in shale. Meanwhile, microfractures also develop under high formation pressure, which can increase the storage space of shale and also can lay a foundation for fracturing construction and artificial fracture expansion in the later stage.

\section{Conclusions}

The following conclusions were drawn from this study:

(1) Based on the petrological characteristics, genesis, and morphological distribution of different organic matters, the organic matter could be divided into two types: organic matter in situ and migrated organic matter. The migrated organic matter included solid 
bitumen that is found in interparticle pores of silicates, while the organic matter in situ is found in interparticle pores of clay minerals and pyrite

(2) The pore size, shape coefficient, and fractal dimension are different for organic matter in situ or migrated organic matter and change with wells moving toward the Qiyueshan fault. In organic matter in situ, porosity is mainly represented by isolated micropores and a few mesopores. Affected by the plasticity of organic matter, pores in the organic matter in situ are complex in morphology but directional distribution

(3) The development of organic pores in the Dingshan field is predominantly controlled by the formation pressure. Overpressure could mitigate the stress acting on the rock skeleton by reducing the compaction of interstitial migratory organic matter at the edge of minerals. The morphology of organic matter pores is almost round and the diameter of the pores is larger when the pressure coefficient is higher than 1.2, indicating that overpressure provided positive protection for the preservation of organic matter pores in shale. Besides, microfractures develop under high formation pressure, which can increase the shale storage space and also can lay a foundation for fracturing construction and artificial fracture expansion in the later stage

\section{Data Availability}

The data are attached to the article.

\section{Conflicts of Interest}

The authors declare that they have no conflicts of interest.

\section{Acknowledgments}

This study is supported by the Central Government Guide Local Science and Technology Development Special Project of 2020 (No. 2020ZYD027).

\section{References}

[1] Z. Chen, Y. Song, Z. Jiang et al., "Identification of organic matter components and organic pore characteristics of marine shale: a case study of Wufeng-Longmaxi shale in southern Sichuan Basin, China," Marine and Petroleum Geology., vol. 109, pp. 56-69, 2019.

[2] M. E. Curtis, B. J. Cardott, C. H. Sondergeld, and C. S. Rai, "Development of organic porosity in the Woodford Shale with increasing thermal maturity," International Journal of Coal Geology., vol. 103, pp. 26-31, 2012.

[3] R. G. Loucks, R. M. Reed, S. C. Ruppel, and U. Hammes, "Spectrum of pore types and networks in mudrocks and a descriptive classification for matrix-related mudrock pores," AAPG Bulletin., vol. 96, no. 6, pp. 1071-1098, 2012.

[4] B. J. Cardott, C. R. Landis, and M. E. Curtis, "Post-oil solid bitumen network in the Woodford Shale, USA - a potential primary migration pathway," International journal of coal geology., vol. 139, pp. 106-113, 2015.

[5] K. L. Milliken, W. L. Esch, R. M. Reed, and T. Zhang, "Grain assemblages and strong diagenetic overprinting in siliceous mudrocks, Barnett Shale (Mississippian), Fort Worth Basin, Texas," AAPG Bulletin, vol. 96, no. 8, pp. 1553-1578, 2012.

[6] W. Zhang, W. Hu, T. Borjigin, and F. Zhu, "Pore characteristics of different organic matter in black shale: a case study of the Wufeng-Longmaxi Formation in the Southeast Sichuan Basin, China," Marine and Petroleum Geology, vol. 111, pp. 33-43, 2020.

[7] L. Huang and W. Shen, "Characteristics and controlling factors of the formation of pores of a shale gas reservoir: a case study from Longmaxi Formation of the Upper Yangtze region," China Earth Science Frontiers, vol. 22, pp. 374-385, 2015.

[8] N. Peng, S. He, Q. Hu et al., "Organic nanopore structure and fractal characteristics of Wufeng and lower member of Longmaxi shales in southeastern Sichuan, China," Marine and Petroleum Geology., vol. 103, pp. 456-472, 2019.

[9] P. C. Hackley and B. J. Cardott, "Application of organic petrography in North American shale petroleum systems: a review," International journal of coal geology., vol. 163, pp. 8-51, 2016.

[10] M. Mastalerz and M. Glikson, "In-situ analysis of solid bitumen in coal: examples from the Bowen Basin and the Illinois Basin," International Journal of Coal Geology., vol. 42, no. 23, pp. 207-220, 2000.

[11] B. Tissot and D. Welte, Petroleum Formation an Occurrence, Springer, Verlag, Berlin, Heidelberg, 1984.

[12] J. A. Curiale, "Origin of solid bitumens, with emphasis on biological marker results," Organic Geochemistry., vol. 10, no. 1-3, pp. 559-580, 1986.

[13] F. Galasso, P. Fernandes, G. Montesi, J. Marques, A. Spina, and Z. Pereira, "Thermal history and basin evolution of the Moatize - Minjova Coal Basin (N'Condedzi sub-basin, Mozambique) constrained by organic maturation levels," Journal of African Earth Sciences., vol. 153, pp. 219-238, 2019.

[14] H. Jacob, "Classification, structure, genesis and practical importance of natural solid oil bitumen ("migrabitumen")," International Journal of Coal Geology, vol. 11, no. 1, pp. 6579, 1989.

[15] S. Cirilli, N. Buratti, L. Gugliotti, and A. Frixa, "Palynostratigraphy and palynofacies of the Upper Triassic Streppenosa Formation (SE Sicily, Italy) and inference on the main controlling factors in the organic rich shale deposition," Review of Palaeobotany and Palynology., vol. 218, pp. 67-79, 2015.

[16] A. Sorci, S. Cirilli, G. Clayton et al., "Palynomorph optical analyses for thermal maturity assessment of Upper Ordovician (Katian-Hirnantian) rocks from Southern Estonia," Marine and Petroleum Geology., vol. 120, p. 104574, 2020.

[17] A. Schito, A. Spina, S. Corrado, S. Cirilli, and C. Romano, "Comparing optical and Raman spectroscopic investigations of phytoclasts and sporomorphs for thermal maturity assessment: the case study of Hettangian continental facies in the Holy Cross Mts. (Central Poland)," Marine and Petroleum Geology., vol. 104, pp. 331-345, 2019.

[18] A. Riboulleau, A. Spina, M. Vecoli et al., "Organic matter deposition in the Ghadames Basin (Libya) during the Late Devonian-a multidisciplinary approach," Palaeogeography, Palaeoclimatology, Palaeoecology., vol. 497, pp. 37-51, 2018. 
[19] A. Schito, S. Corrado, M. Trolese et al., "Assessment of thermal evolution of Paleozoic successions of the Holy Cross Mountains (Poland)," Marine and Petroleum Geology., vol. 80, pp. 112-132, 2017.

[20] S. Cirilli, G. Panfili, N. Buratti, and A. Frixa, "Paleoenvironmental reconstruction by means of palynofacies and lithofacies analyses: an example from the Upper Triassic subsurface succession of the Hyblean Plateau Petroleum System (SE Sicily, Italy)," Review of Palaeobotany and Palynology., vol. 253, pp. 70-87, 2018.

[21] J. H. Zhao, Z. J. Jin, and Z. K. Jin, "Petrographic methods to distinguish organic matter type in shale," Petroleum Geology \& Experiment., vol. 38, no. 4, pp. 514-520, 2016.

[22] Z. Z. Liu, M. G. Bai, and Y. R. Yang, "Discussion on the genesis and exploration potential of different microscopic forms of organic matters in the Longmaxi formation shale," Rock and Mineral Analysis., vol. 39, no. 2, pp. 199-207, 2020.

[23] M. G. Bai, X. H. Xia, and C. Zhang, "Study on shale organic porosity in the Longmaxi formation, AnYe-1 well using field emission-scanning electron microscopy and PerGeos system," Rock and Mineral Analysis., vol. 37, no. 3, pp. 225-234, 2018.

[24] H. Zhang, X. L. Jin, and J. Wu, "Nano-pores of organic matter in Longmaxi Formation shale in Sichuan basin," Coal Geology \& Exploration., vol. 46, no. 3, pp. 47-53, 2018.

[25] M. Mastalerz, A. Drobniak, and A. B. Stankiewicz, "Origin, properties, and implications of solid bitumen in source-rock reservoirs: a review," International Journal of Coal Geology., vol. 195, pp. 14-36, 2018.

[26] T. Dong, S. He, M. Chen et al., "Quartz types and origins in the paleozoic Wufeng-Longmaxi Formations, Eastern Sichuan Basin, China: implications for porosity preservation in shale reservoirs," Marine and Petroleum Geology., vol. 106, pp. 6273, 2019.

[27] Q. Zhang, R. Liu, Z. Pang, W. Lin, W. Bai, and H. Wang, "Characterization of microscopic pore structures in Lower Silurian black shale $\left(\mathrm{S}_{1} \mathrm{l}\right)$, southeastern Chongqing, China," Marine and Petroleum Geology, vol. 71, pp. 250-259, 2016.

[28] F. L. Lu, W. H. Liu, and J. G. Cai, "Influence of shale clay mineral pore structure and hydrocarbon occurrence space on unconventional oil and gas exploration," in The 3rd Unconventional Oil and Gas Accumulation and Exploration Evaluation Symposium, Geological Society of China and China Petroleum Institute, Qingdao, China, 2015.

[29] S. Bernard, B. Horsfield, H.-M. Schulz, R. Wirth, A. Schreiber, and N. Sherwood, "Geochemical evolution of organic-rich shales with increasing maturity: a STXM and TEM study of the Posidonia Shale (Lower Toarcian, northern Germany)," Marine and Petroleum Geology., vol. 31, no. 1, pp. 70-89, 2012.

[30] D. J. K. Ross and R. M. Bustin, “The importance of shale composition and pore structure upon gas storage potential of shale gas reservoirs," Marine and Petroleum Geology., vol. 26, no. 6, pp. 916-927, 2009.

[31] Q. Cao, W. Zhou, H. Deng, and W. Chen, "Classification and controlling factors of organic pores in continental shale gas reservoirs based on laboratory experimental results," Journal of Natural Gas Science and Engineering., vol. 27, pp. 13811388, 2015.

[32] C. Er, Y. Li, J. Zhao, R. Wang, Z. Bai, and Q. Han, "Pore formation and occurrence in the organic-rich shales of the Triassic Chang-7 Member, Yanchang Formation, Ordos Basin, China," Natural Gas Geoscience., vol. 1, no. 6, pp. 435-444, 2016.
[33] Q. Cao, Characterization and Techniques of Micropores in Organic-Rich Shale of Chang 7th of Yanchang Formation, Chengdu University of Technology, Ordos Basin Chengdu, 2016.

[34] Z. Y. Gao, Y. P. Fan, and Q. H. Hu, "Differential development characteristics of organic matter pores and their impact on reservoir space of Longmaxi Formation shale from the South Sichuan Basin," Petroleum Science Bulletin., vol. 5, no. 1, pp. 1-16, 2020.

[35] Q. Wang, X. F. Wei, and F. B. Wei, “Overpressure in shale gas reservoirs of Wufeng-Longmaxi formations, Fuling area, southeastern Sichuan Basin," Petroleum Geology \& Experiment, vol. 41, no. 3, pp. 333-340, 2019.

[36] J. Wu, Z. Q. Hu, and J. Xie, "Macro-micro occurrence mechanism of organic matters in Wufeng-Longmaxi shale in the Sichuan Basin and its peripheral areas," Natural Gas Industry., vol. 38, no. 8, pp. 23-32, 2018.

[37] Y. F. Yunfeng, B. Fang, and B. Tenger, "Characteristics of organic matter? Hosted pores in Lower Silurian Longmaxi shale with different maturities, Sichuan Basin," Petroleum Geology and Experiment., vol. 42, no. 3, pp. 387-397, 2020.

[38] W. M. Huang, S. G. Liu, and G. S. Xu, "Characteristics of paleo oil pools from Sinian to lower Paleozoic in southeastern margin of Sichuan Basin," Geological Review., vol. 57, no. 2, pp. 286-299, 2011.

[39] W. G. Hu, F. G. Li, and C. H. Fan, "Prediction and evaluation on deeper marine shale-gas reservoirs, Dingshan area, Sichuan Basin," Natural Gas Exploration and Development., vol. 42, no. 3, pp. 66-77, 2019.

[40] Q. Ran, Y. Chen, and Q. Qi, "Preservation conditions of shale gas in Longmaxi formation of Dingshan area," Petroleum Geology and Engineering., vol. 31, no. 4, pp. 22-25, 2017.

[41] X. S. Guo, D. F. Hu, and R. B. Liu, "Geological conditions and exploration potential of Permian marine-continent transitional facies shale gas in the Sichuan Basin," Natural Gas Industry., vol. 38, no. 10, pp. 11-18, 2018.

[42] Z. Y. Lu, Z. L. He, and C. Yu, "Characteristics of shale gas enrichment in tectonically complex regions-a case study of the Wufeng-Longmaxi Formations of Lower Paleozoic in southeastern Sichuan Basin," Oil \& Gas Geology., vol. 42, no. 1, pp. 86-97, 2021.

[43] M. Y. Zhu, Structural Characteristics and Shale Gas Preservation Conditions of Wufeng-Longmaxi Formation in Dingshan Area, Southwest Petroleum University, Chengdu, 2018.

[44] W. Sun, S. G. Liu, and G. Z. Wang, "Petroleum formed condition and process research for Sinian to Low Paleozoic at Dingshan structure in southeast of Sichuan Basin," Geological Science and Technology Information., vol. 29, no. 1, pp. 49$55,2010$.

[45] S. He, Q. R. Qin, and F. C. Hui, "Shale gas preservation conditions in Dingshan area, southeastern Sichuan," Petroleum Geology and Recovery Efficiency., vol. 26, no. 2, pp. 24-31, 2019.

[46] X. F. Wei, Z. B. Zhao, and Q. B. Wang, "Comprehensive evaluation on geological conditions of the shale gas in Upper Ordovician Wufeng formation -Lower Silurian Longmaxi formation in Dingshan area, Qijiang, Southeastern Sichuan," Geological Review, vol. 63, no. 1, pp. 153-164, 2017.

[47] G. X. Feng and S. J. Chen, "Relationship between the reflectance of bitumen and vitrinite in rock," Natural Gas Industry., vol. 8 , no. 3 , pp. $20-25,1988$. 
[48] C. R. Landis and J. R. Castano, "Maturation and bulk chemical properties of a suite of solid hydrocarbons," Organic Geochemistry., vol. 22, no. 1, pp. 137-149, 1995.

[49] H. I. Petersen, N. H. Schovsbo, and A. T. Nielsen, "Reflectance measurements of zooclasts and solid bitumen in Lower Paleozoic shales, southern Scandinavia: correlation to vitrinite reflectance," International Journal of Coal Geology., vol. 114, pp. 1-18, 2013.

[50] R. Bertrand and M. Malo, Dispersed Organic Matter Reflectance and Thermal Maturation in Four Hydrocarbon Exploration Wells in the Hudson Bay Basin: Regional Implications, Geological Survey of Canada, 2012.

[51] L. F. Lu, J. G. Cai, and W. H. Liu, "Occurrence and thermostability of absorbed organic matter on clay minerals in mudstones and muddy sediments," Oil \& Gas Geological., vol. 34, no. 1, pp. 16-26, 2013.

[52] Y. Chen, Research on Reservoir Characteristics and Sweet Spot Prediction Technology of Shale Gas of Wufeng-Longmaxi Formation in Jiaoshiba and Dingshan Area, Chengdu University of Technology, Chengdu, 2016.

[53] N. S. Qiu, Q. Q. Feng, and T. Borjigin, "Yanshanian-Himalayan differential tectono-thermal evolution and shale gas preservation in Dingshan area, southeastren Sichuan Basin," Acta Petrolei Sinica, vol. 41, no. 12, pp. 1610-1622, 2020.

[54] S. G. Liu, W. Sun, and Z. W. Li, "Tectonic uplifting and gas pool formation since Late Cretaceous epoch Sichuan Basin," Natural Gas Geoscience, vol. 19, no. 3, pp. 293-300, 2008.

[55] C. Zhong, Fracture Characteristics of Longmaxi Formation Shale and Its Relationship with Gas Content in Dingshan Area, Southeastern Sichuan Basin, Southwest Petroleum University, Chengdu, 2019.

[56] J. L. Fu, W. L. Ding, and W. T. Zeng, "Influence of structure of northwest Guizhou area on preservation of Lower Cambrian shale gas reservoirs," Journal of Southwest Petroleum University (Science \& Technology Edition), vol. 38, no. 5, pp. 22-32, 2016.

[57] D. M. Jarvie, R. J. Hill, T. E. Ruble, and R. M. Pollastro, "Unconventional shale-gas systems: the Mississippian Barnett Shale of north-central Texas as one model for thermogenic shale-gas assessment," AAPG Bulletin., vol. 91, no. 4, pp. 475-499, 2007.

[58] R. Y. Wang, H. K. Nie, and Z. Q. Hu, "Controlling effect of pressure evolution on shale gas reservoirs: a case study of the Wufeng-Longmaxi Formation in the Sichuan Basin," Natural Gas Industry., vol. 40, no. 10, pp. 1-11, 2020.

[59] R. Y. Wang, W. L. Ding, and D. J. Gong, "Gas preservation conditions of marine shale in northern Guizhou area: a case study of the Lower Cambrian Niutitang Formation in the Cen'gong block, Guizhou Province," Oil and Gas Geology, vol. 37, no. 1, pp. 45-55, 2016.

[60] J. D. Hughes, Drilling Deeper: A Reality Check on U.S. Government Forecasts for a Lasting Tight Oil \& Shale Gas Boom, California Post Carbon Institute, Santa Rosa, 2014.

[61] H. L. Liu, X. B. Liu, and S. W. Zhou, "Phenomenon of bubble evolving into pore occurred in black shale and its geological significance," Natural Gas and Oil., vol. 36, no. 6, pp. 60-64, 2018.

[62] J. H. Ding, J. C. Zhang, and C. Yang, "Formation evolution and influencing factors of organic pores in shale," Journal of Southwest Petroleum University (Science \& Technology Edition), vol. 41, no. 2, pp. 33-44, 2019. 